\title{
PERSEPSI WISATAWAN LOKAL TERHADAP PENYEDIAAN FASILITAS OBJEK TAMAN WISATA ALAM PUNTI KAYU DI KECAMATAN ALANG-ALANG LEBAR KOTA PALEMBANG
}

\author{
Enno Lerian ${ }^{1}$, Maharani Oktavia ${ }^{2}$ \\ 2 Prodi Pendidikan Geografi Universitas PGRI Palembang \\ $(\Xi)$ maharanigeo@gmail.com²
}

\begin{abstract}
ABSTRAK
Penyediaan fasilitas objek wisata merupakan salah satu faktor pendukung dalam kegiatan pengembangan kepariwisataan. Objek taman wisata alam punti kayu memiliki berbagai macam fasilitas yang di sediakan untuk dapat dinikmati oleh para wisatawan. Tujuan dalam penelitian ini adalah untuk mengetahui persepsi wisatawan lokal terhadap penyediaan fasilitas objek taman wisata alam punti kayu di Kecamatan Alang-Alang Lebar Kota Palembang. Metode penelitian ini menggunakan metode deskritif kualitatif dengan teknik pengumpulan data yang digunakan yaitu observasi, angket, wawancara dan dokumentasi. Teknik analisis data dalam penelitian ini menggunakan distribusi frekuensi. Hasil penelitian menunjukkan bahwa hampir secara keseluruhan fasilitas yang disediakan di objek taman wisata alam punti kayu sudah baik hanya ada beberapah saja atau sebagian kecil dari fasilitas yang masih dinilai belum baik dan cukup baik. Adapun fasilitas yang dinilai sudah baik antara lain replika/miniatur 7 keajaiban dunia, kolam renang, musholla, wc umum, sedangkan fasilitas yang dinilai cukup baik antara lain tempat berteduh, tempat sampah, kantin/pondok pedagang, dan kursi. Serta fasilitas yang dinilai belum baik antara lain kebun binatang mini (jenis hewan yang berada dikebun mini masih sedikit). Perlu adanya perbaikkan untuk fasilitas yang dianggap belum baik seperti perawatan kandang hewan, penambahan jenis hewan, dan juga pemeliharaan terhadap fasilitas yang sudah ada tersedia agar kondisinya tetap terjaga.
\end{abstract}

\section{Kata Kunci : Persepsi, Wistawan Lokal, Fasilitas Wisata, Objek Wisata}

\section{PENDAHULUAN}

Indonesia sebagai Negara agraris memiliki kekayaan alam yang dapat dimanfaatkan oleh berbagai sektor, diantaranya adalah sektor pariwisata. Pariwisata merupakan salah satu sektor yang menjadi tumpuan bagi pemerintah untuk meningkatkan kondisi perekonomian negara. Peranan utama sektor pariwisata dalam hal perekonomian Indonesia adalah sebagai penambah devisa negara. Devisa negara dihasilkan dari besarnya pengeluaran wisatawan mancanegara yang berkunjung ke Indonesia. Perolehan devisa negara dari sektor pariwisata tahun 2012 sebesar 9 milyar dolar AS. Angka ini menempatkan sektor pariwisata di peringkat kelima penyumbang devisa negara terbesar. Nilai tersebut lebih besar 5,8 persen dibandingkan perolehan tahun 2011 sebesar 8,5 miliyar dolar AS (Stevianus:2014).

Perkembangan di era globalisasi dan peningkatan taraf serta gaya hidup masyarakat mengakibatkan munculnya fenomena bergesernya kebutuhan masyarakat dari pemenuhan kebutuhan primer ke pemenuhan kebutuhan sekunder dan tersier. Masyarakat sebagai konsumen membutuhkan produk yang dapat memenuhi kebutuhan mereka akan hiburan dan kesenangan. Peningkatan kebutuhan konsumen akan jasa wisata berakibat pada semakin meningkatnya jumlah kunjungan wisatawan. Menurut Wardiyanto (2011:8) wisatawan adalah setiap orang yang berpergian dari tempat tinggalnya untuk berkunjung ke tempat lain dengan tujuan 
menikmati perjalananan yang dilakukan dari kunjungan itu.

Jumlah kunjungan wisatawan setiap tahunnya menunjukkan bahwa sektor pariwisata terus mengalami pertumbuhan dan berpotensi untuk dikembangkan. Salah satu daerah tujuan wisata Provinsi Sumatera Selatan merupakan wilayah yang mempunyai banyak tempat wisata dan kaya akan keanekaragaman hayati. Khususnya di Kota Palembang banyak tempat-tempat wisata yang dapat di kunjungi, salah satunya adalah objek wisata alam punti kayu Palembang. Objek wisata alam ini merupakan sebagian dari aset wisata yang ada di Palembang bahkan sudah dikenal oleh masyarakat umum.

Taman wisata alam punti kayu merupakan satu satunya hutan wisata di kota palembang yang terletak $7 \mathrm{~km}$ dari pusat kota, memiliki luas lahan sekitar 50 ha. Kawasan taman punti kayu merupakan kawasan konservasi yang konsep pengembangannya berdasarkan prinsip-prinsip perlindungan keanekaragaman jenis tumbuhan hayati dan satwa. Taman wisata alam punti kayu memiliki potensi berupah Panorma Hutan Pinus (pinus mercussi) yang memiliki nilai estetika pemandangan menarik, serta adanya kebun binatang mini/sarana edukasi dengan hewan liar yaitu kera ekor panjang (macaca fasicicularis), beruk (macaca nemistriana), dan berbagai macam fasilitas yang di miliki oleh objek wisata Punti Kayu dimana fasilitas. Menurut Yoeti (2000) dalam Suchaina, (2014:90) "Prasarana kepariwisataan adalah semua fasilitas yang memungkinkan agar sarana kepariwisataan dapat hidup dan berkembang sehingga dapat memberikan pelayanan untuk memuaskan kebutuhan wisatawan yang beraneka ragam sehingga wisatawan juga tertarik untuk berkunjung ke suatu tempat wisata".

Berdasarkan Observasi awal Fasilitas Objek Wisata Punti Kayu Palembang sudah memadai baik dari Fasilitas Pokok, Penunjang dan Pelengkap. Terlihat dari adanya Infrastruktur sudah baik dilihat dari kondisi jalan yang dilalui wisatawan lancar, Kebun Binatang Mini, Kolam Renang, Pintu Gerbang, Loket Karcis, Mushollah, Toilet Umum, Kantin/Pondok Pedagang, Tempat
Berteduh, Pos Keamanan, Tempat Sampah dan Tempat Parkir yang luas. Kemudian di tahun 2016 adanya penambahan Fasilitas Miniatur 7 keajaiban dunia yang terkenal didunia seperti Candi Borobudur, Menara Eifel, Piramid Mesir, dan Menara Pisa. Dari berbagai fasilitas tersebut membuat punti kayu menjelma menjadi arena wisata keluarga yang menarik, dan diminati masyarakat terutama pada Momentum seperti Libur Sekolah, Hari Besar Keagamaan, dan Akhir Pekan terlihat dari jumlah pengunjung mengalami peningkatan 2000-5000 pengunjung (Tribunnews:2017). Selain hari libur jumlah pengunjung mengalami peningkatan di karenakan adanya Penambahan Wahana 7 Keajaiban Dunia terlihat dari jumlah pengunjung yang membludak terutama pada tanggal 1, 2, dan 3 Januari 2017 mencapai 5000-1000 pengunjung yang datang ke Objek Wisata Punti Kayu Palembang (Abdullah:2017).

Namun pada kenyataannya masih ada saja terdapat beberapa fasilitas-fasilitas yang tersedia di sana yang tidak sesuai dengan yang diharapkan seperti kurangnya penyediaan tempat sampah terlihat dari sampah yang berserakan, kurangnya perawatan kandang hewan terlihat dari jumlah jenis hewan yang berada di kebun binatang mini jumlahnya berkurang/masih sedikit, tidak ada hewan langka dikebun binatang mini, sehinggah pengunjung yang datang ke objek taman wisata alam punti kayu merasa kurang puas terhadap penyediaan fasilitas kebun binatang mini karena jumlah hewan yang berada di kebun mini jumlahnya sedikit dan hewan yang dijumpai di kebun binatang mini tersebut hewannya masih jenis hewan yang sering ditemui. Kemudiaan kurangnya pengoptimalan fungsi kolam renang terlihat dari kolam terlihat sepi dan hanya difungsikan pada hari-hari tertentu saja.

Hal ini sangat disayangkan karena objek wisata alam punti kayu ini salah satu objek wisata alam di Kota Palembang yang memiliki potensi bagi perkembangan kegiatan pariwisata di Kota Palembang dan salah satu cara memunculkan potensi pada objek wisata tersebut adalah dengan menyediakan fasilitas-fasilitas wisata yang baik dan benar-benar memadai dan dapat digunakan 
oleh para pengunjung terutama wisatawan lokal. Dengan demikian pengelolah hutan wisata punti kayu terus melakukan pembenahan serta perawatan tanaman dan penambahan fasilitas. Rencananya di tahun 2017 ini objek wisata alam Punti Kayu akan melengkapi koleksi replica keajaiban dunia seperti akan dibangun Tembok Besar Cina, Menara Jam Besar seperti yang ada di Inggris (Antoni dalam Radar Palembang:2016).

Perbaikan maupun penambahan fasilitas wisata dalam berbagai segi terutama pada penyedian fasilitas-fasilitas yang ada pada setiap objek wisata sebagai salah satu daya tarik wisatawan untuk berkunjung lagi. Dengan memberikan kenyamanan pada fasilitas-fasilitas yang disediakan maka hal ini dapat meningkatkan jumlah kunjungan para wisatawan dari tahun ketahun tak kecuali dengan para wisatawan lokal yang ingin berwisata dengan lokasi yang mudah di jangkau. Pembenahan dan penambahan fasilitas serta perawatan tanaman terus dilakukan agar pengunjung dapat lebih nyaman dan untuk menambah daya tarik masyarakat dan wisatawan nusantara dan mancanegara untuk berkunjung ke objek wisata alam Punti Kayu di Kota Palembang.

\section{METODOLOGI PENELITIAN}

Metode yang digunakan dalam penelitian ini adalah metode deskritif kualitatif. Kualitatif adalah data penelitian yang diwujudkan dalam kata keadaan atau kata sifat baik itu lisan maupun tertulis yang di cermati peneliti (Arikunto 2013:21). Dalam penelitian ini menggunakan dua macam klasifikasi data yang didasarkan pada jenis dan sumber data, yaitu data primer dan data sekunder. Data primer diperoleh melalui observasi, wawancara dan dokumentasi sedangkan data sekunder diperoleh melalui Dinas Pariwisata Kota Palembang dan Badan Pusat Statistik (BPS) Kota Palembang.

Teknik analisis data dalam penelitian ini adalah metode deskriptif kualitatif dengan menggunakan analisis tabel frekuensi, editing, koding, dan tabulasi data. Setelah data disusun dan dihitung kemudian disajikan dalam bentuk tabel. Skala pengukuran dalam penelitian ini menggunakan Skala Likert. Skala likert digunakan untuk mengukur sikap, pendapat, dan persepsi seseorang.

\section{HASIL dan PEMBAHASAN}

\section{Hasil Penelitian}

Adapun hasil data dari kuesioner akan dijabarkan lebih rinci untuk tiap-tiap indikatornya.

1. Persepsi Wisatawan Lokal Terhadap

Penyediaan Fasilitas Kolam Renang

Persepsi wisatawan terhadap penyediaan kolam renang di objek taman wisata alam punti kayu dikategorikan cukup baik. Hal ini dapat dilihat dari diagram dibawah ini.

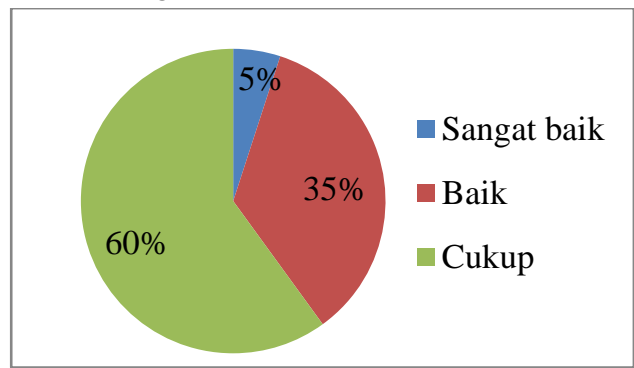

Gambar 1. Diagram persepsi wisatawan terhadap penyediaan kolam renang

2. Persepsi Wisatawan Terhadap Kebersihan Lingkungan Sekitar Kolam Renang

Persepsi wisatawan terhadap kebersihan lingkungan sekitar kolam renang dapat dilihat dari diagram berikut.

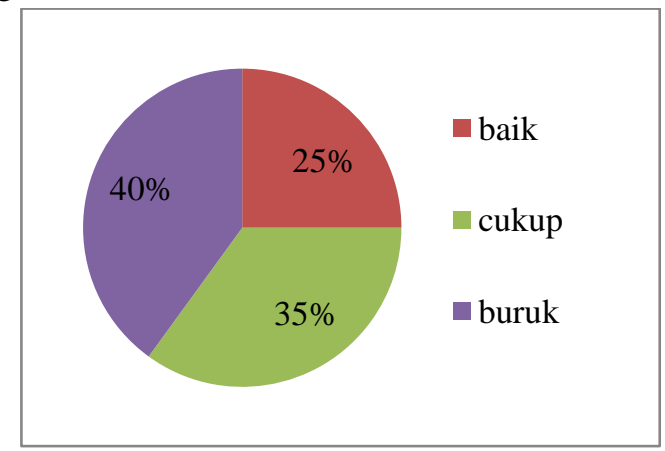

Gambar 2. Diagram persepsi wisatawan terhadap kebersihan lingkungan sekitar kolam renang

3. Persepsi Wisatawan Terhadap Penyediaan Fasilitas Kebun Binatang Mini

Berdasarkan tabel diatas tentang persepsi wisatawan terhadap jumlah hewan yang ada di kebun binatang mini dapat dilihat pada gambar diagram 3 berikut. 


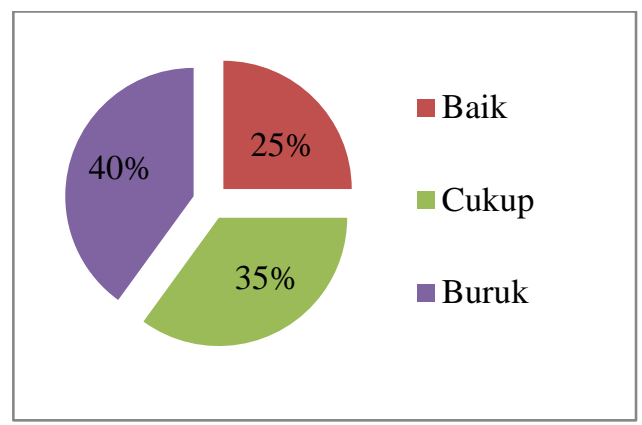

Gambar 3. Diagram persepsi wisatawan terhadap jumlah hewan yang ada di kebun binatang mini

4. Persepsi Wisatawan Terhadap Kebun Binatang Mini Sebagai Sarana Edukasi

Pendapat wisatawan terhadap kebun binatang mini sebagai sarana Edukasi cukup baik. Dapat dilihat pada gambar diagram 4 dibawah ini.

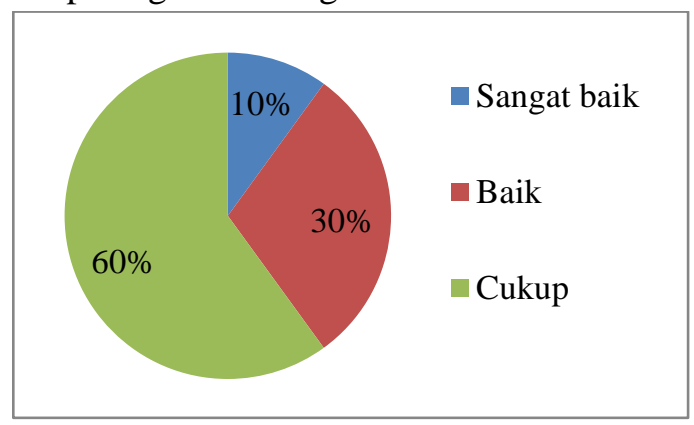

Gambar 4. Diagram persepsi wisatawan terhadap kebun binatang mini sebagai sarana Edukasi

5. Persepsi Wisatawan Terhadap Penyedian Fasilitas Replika/Miniatur 7 Keajaiban Dunia

Persepsi wisatawan terhadap bangunan replika/miniatur 7 keajaiban yaitu baik dapat dilihat pada gambar diagram dibawah ini.



Gambar 5. Diagram persepsi wisatawan terhadap bangunan replika/7 keajaiban dunia

6. Persepsi Wisatawan Terhadap Daya Tarik Dari Replika/Miniatur 7 Keajaiban Dunia

Pendapat wisatawan Terhadap Daya Tarik Dari Replika/Miniatur 7 Keajaiban Dunia dapat dilihat pada gambar diagram berikut:

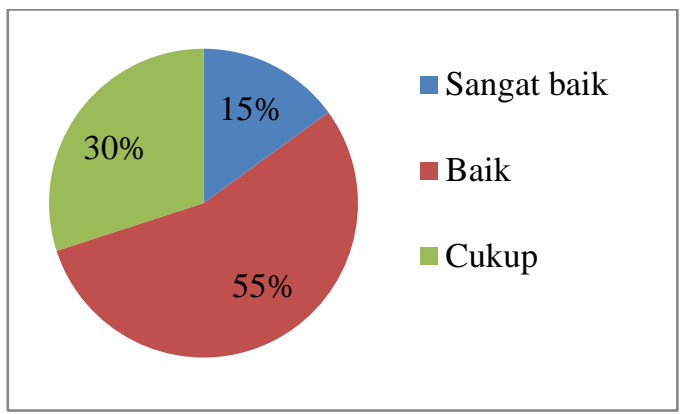

Gambar 6. Diagram persepsi wisatawan terhadap daya tarik replika miniatur 7 keajaiban dunia

7. Persepsi Wisatawan Terhadap Penyediaan Fasilitas Musholla

Persepsi Wisatawan Terhadap Kelengkapan Musholla yang ada di objek taman wisata alam punti kayu dapat dilihat pada gambar diagram berikut:

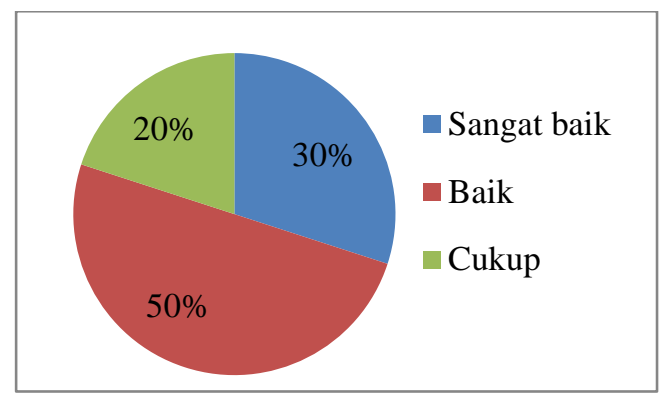

Gambar 7. Diagram persepsi wisatawan terhadap kelengkapan musholla

8. Persepsi Wisatawan Terhadap Kenyamanan Musholla

Persepsi Wisatawan Terhadap Kenyamanan Musholla yang disediakan oleh pihak pengelolah yaitu sudah baik dapat dilihat pada gambar diagram berikut.

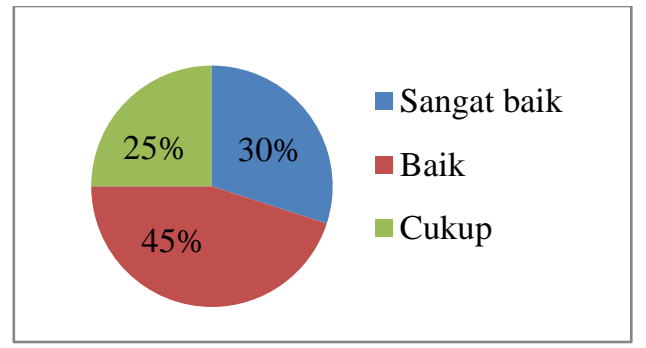

Gambar 8. Diagram Persepsi Wisatawan Terhadap Kenyamanan Musholla

9. Persepsi Wisatawan Terhadap Nyediaan Fasilitas Wc Umum

Fasilitas wc umum yang ada di objek wisata jumlahnya cukup banyak, hal ini agar wisatawan yang berkunjung tidak berdesakkan 
mengunakannya. Adapun Indikator untuk fasilitas wc umum terbagi menjadi 3 aspek sebagai berikut:

a. Persepsi Wisatawan Terhadap Kondisi Bangunan Wc Umum

Persepsi Wisatawan Terhadap Kondisi Bangunan Wc Umum yang ada diobjek taman wisata alam punti kayu dapat dilihat pada gambar diagram berikut.

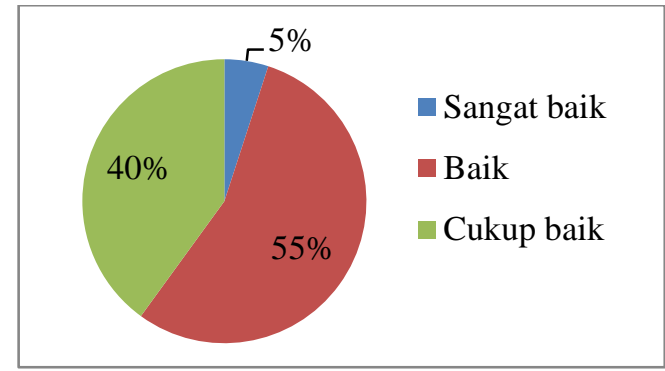

Gambar 9. Diagram Persepsi Wisatawan Terhadap Kondisi Bangunan Wc Umum

b. Persepsi Wisatawan Terhadap Kebersian Wc Umum

Persepsi Wisatawan Terhadap Kebersian Wc Umum dapat dilihat pada gambar diagram berikut.

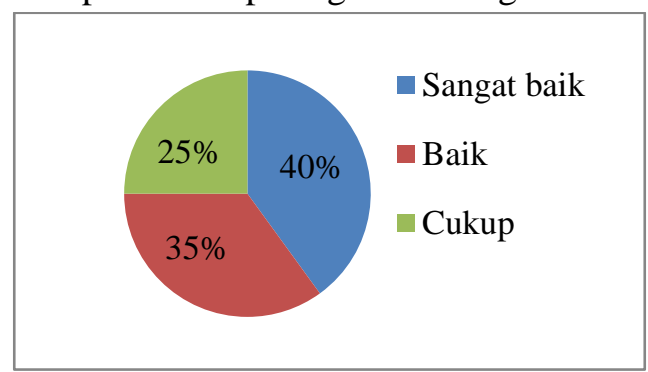

Gambar 10. Diagram persepsi wisatawan terhadap kebersian wc umum

c. Persepsi Wisatawan Terhadap Ketersediaan Air di Wc Umum

Persepsi Wisatawan Terhadap Ketersediaan Air di Wc Umum dapat dilihat pada gambar diagram berikut.

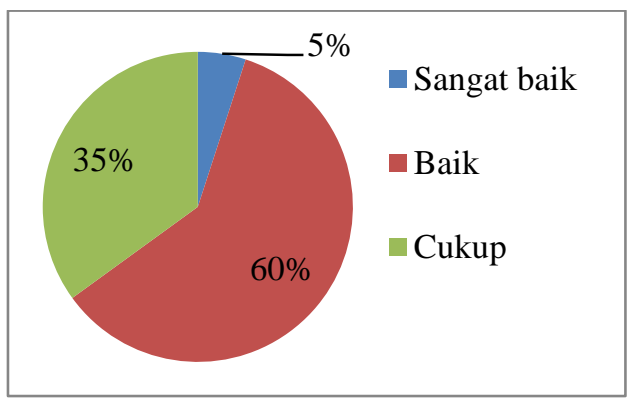

Gambar 11. Diagram persepsi wisatawan terhadap ketersediaan air di wc umum
10. Persepsi Wisatawan Terhadap Nyediaan Fasilitas tempat berteduh

Tempat berteduh/posko berteduh dibangun oleh pihak pengelolah jumlahnya cukup banyak posko tersebut dibuat agar pengunjung dapat bersantai sambil menikmati panaroma hutan pinus. Adapun indikator penilaian yang akan dijabarkan sebagai berikut;

Persepsi Wisatawan Terhadap Bangunan Tempat Berteduh yang disediakan di objek taman wisata alam punti kayu dapat dilihat pada diagram berikut.

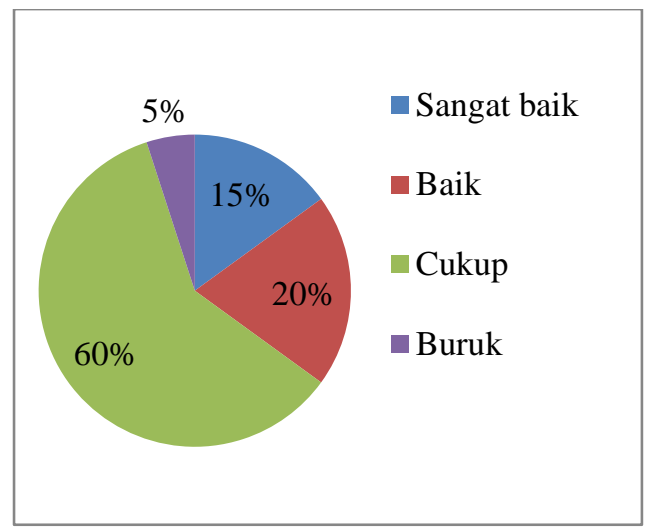

Gambar 12. Diagram persepsi wisatawan terhadap bangunan tempat berteduh

11. Persepsi Wisatawan Terhadap Jumlah Penyediaan Tempat Berteduh

Persepsi Wisatawan Terhadap Jumlah Penyediaan Tempat Berteduh dapat dilihat pada gambar diagram berikut.

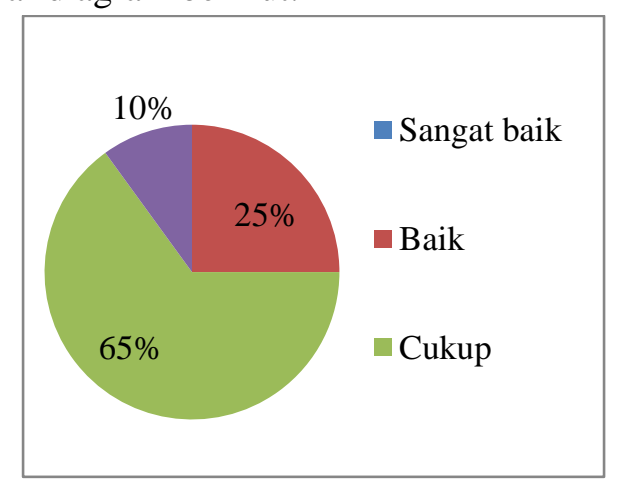

Gambar 13. Diagram persepsi wisatawan terhadap jumlah penyediaan tempat berteduh dapat dilihat

12. Persepsi Wisatawan Terhadap Nyediaan Fasilitas Kursi

Persepsi Wisatawan Terhadap Jumlah Penyediaan Kursi dapat dilihat pada gambar diagram berikut. 


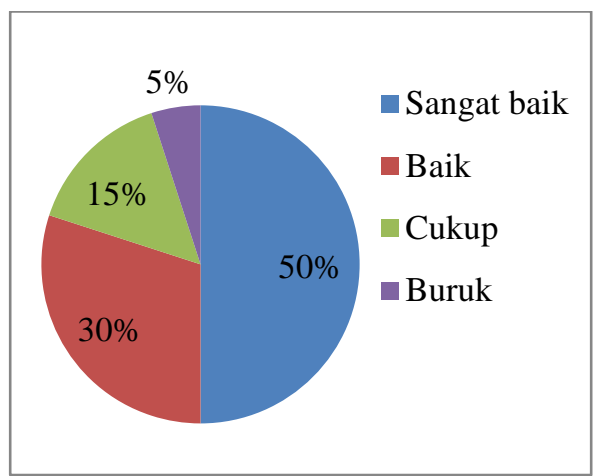

Gambar 14. Diagram persepsi wisatawan terhadap jumlah penyediaan kursi

13.Persepsi Wisatawan Terhadap Kelayakan Kursi

Persepsi Wisatawan Terhadap Kelayakan Kursi yang disediakan di objek taman wisata alam punti kayu dapat dilihat pada gambar berikut.

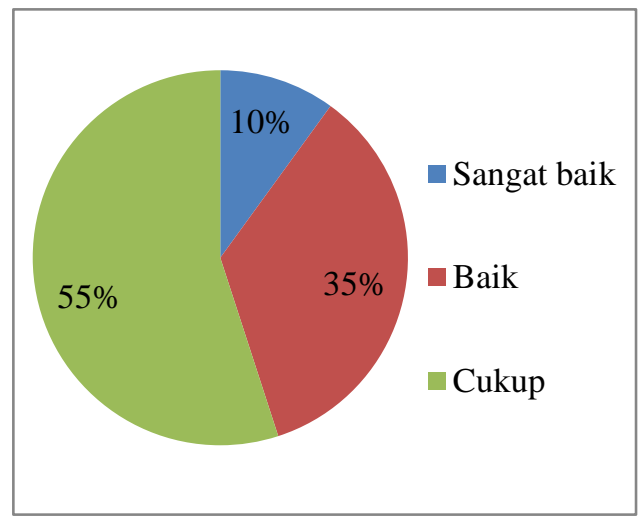

Gambar 15. Diagram persepsi wisatawan terhadap kelayakan kursi

14.Persepsi Wisatawan Terhadap Nyediaan Fasilitas Tempat Sampah

Persepsi Wisatawan Terhadap Jumlah Penyediaan Tempat Sampah yang disediakan di taman wisata alam punti kayu dapat dilihat pada gambar diagram berikut.



Gambar 16. Diagram persepsi wisatawan terhadap jumlah penyediaan tempat sampah
15. Persepsi Wisatawan Terhadap Nyediaan Fasilitas Kantin/Pondok Pedagang

Persepsi Wisatawan Terhadap Kelengkapan Kantin/Pondok Pedagang yang ada di objek taman wisata alam punti kayu dapat dilihat pada diagram 18 berikut:

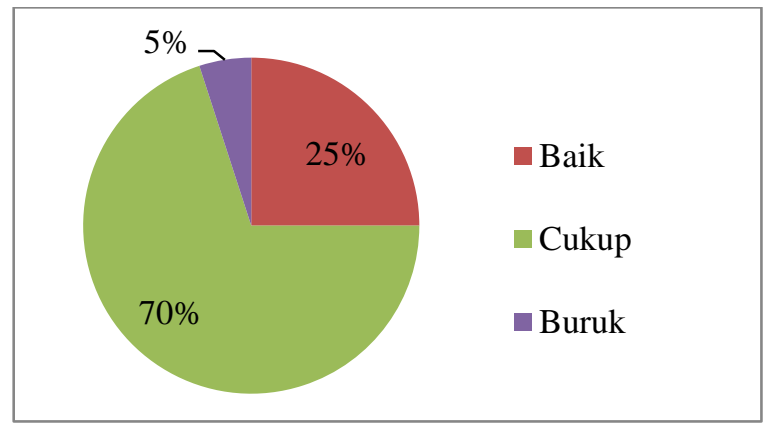

Gambar 17. Diagram persepsi wisatawan terhadap kelengkapan kantin/pondok pedagang

\section{Persepsi Wisatawan Terhadap Pelayanan Kantin/Pondok Pedagang}

Persepsi Wisatawan Terhadap Pelayanan Kantin/Pondok Pedagang yang ada di objek taman wisata alam punti kayu dapat dilihat pada gambar diagram berikut.

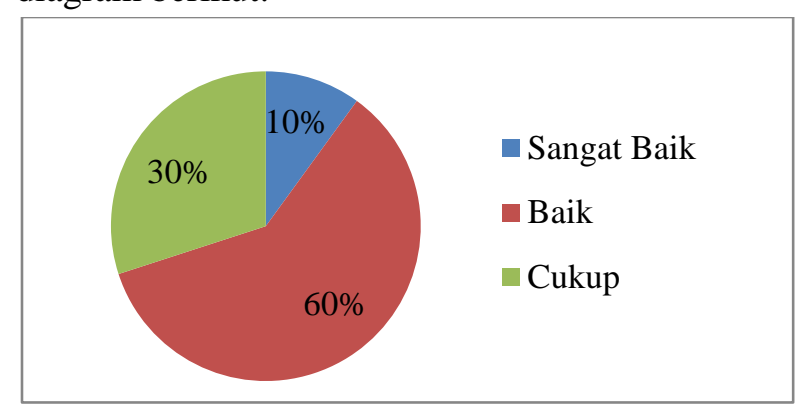

Gambar 18. Diagram persepsi wisatawan terhadap pelayanan kantin/pondok pedagang

17.Persepsi Wisatawan Terhadap Makanan Yang Disediakan Kantin/Pondok Pedagang

Persepsi Wisatawan Terhadap Makanan Yang Disediakan Kantin/Pondok pedagang dapat dilihat pada gambar diagram berikut.

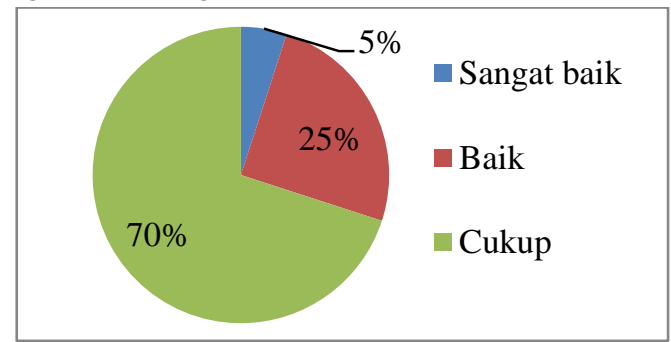

Gambar 19. Diagram persepsi wisatawan terhadap makanan yang disediakan kantin/pondok 


\section{Pembahasan}

Dari hasil penelitian Mengenai Persepsi Wisatawan Lokal Terhadap Penyediaan Fasilitas Objek Taman Wisata Alam Punti Kota Palembang secara detail dan urut dapat disampaikan sebagai berikut: persepsi wisatawan terhadap kolam renang memperoleh nilai cukup baik 60\%, kebersihan air yang berada dikolam renang cukup baik $55 \%$, jenis hewan yang ada dikebun binatang mini memperoleh nilai kurang baik $40 \%$, kebun binatang mini sebagai sarana edukasi cukup baik $60 \%$, bangunan replika/miniatur 7 keajaiban dunia yaitu baik $55 \%$, daya tarik replika/miniatur 7 keajaiban dunia baik 55\%, keyamanan musholla baik $45 \%$, perlengkapan musholla baik 50\%, bangunan wc baik $55 \%$, kebersian wc baik $35 \%$, ketersediaan air di wc baik $60 \%$, bangunan tempat berteduh cukup baik $60 \%$, jumlah tempat berteduh cukup baik $65 \%$, penyediaan kursi sangat baik $50 \%$, kelayakkan kursi baik $35 \%$, penyediaan tempat sampah cukup baik 65\%, kelengkapan kantin/pondok pedagang cukup baik 70\%, pelayanan kantin/pondok pedagang baik 60\%, jenis makanan makananan yang disediakan cukup baik $70 \%$.

\section{SIMPULAN}

Persepsi wisatawan lokal terhadap penyediaan fasilitas objek taman wisata alam Punti Kayu Kota Palembang dilihat dari hasil persentase yang didapat dari jawaban kuesioner bahwa wisatawan yang berkunjung yaitu fasilitas yang dinilai baik antara lain seperti kolam renang, replika/miniatur 7 keajaiban dunia, wc umum, musholla, dan kursi. Sedangkan persepsi wisatawan terhadap fasilitas yang dinilai cukup ialah tempat berteduh, kantin/pondok pedagang serta fasilitas yang masih dianggap kurang baik yaitu kebun binatang mini karena belum banyak jenis hewan yang langka di kebun binatang mini/sarana edukasi. Secara umum persepsi wisatawan yang berkunjung dapat di kategorikan baik dalam penyediaan fasilitas objek wisata. Namun, perlu adanya peningkatan untuk fasilitas yang telah disediakan seperti perbaikkan untuk fasilitas yang di nilai belum baik seperti kebun binatang mini misalnya perawatan kandang hewan, penambahan jenis hewan, dan juga pemeliharaan terhadap fasilitas yang sudah ada tersedia agar kondisinya tetap terjaga.

\section{DAFTAR PUSTAKA}

Abdullah, 2017. Antara Sumsel. Pengelolah Benahi Hutan Wisata Punti Kayu Palembang, terbit Sabtu, 25 Februari 2017 13:42 WIB (Online).(http://m.antarasumsel.com/berita/312 163/pengelolah benahi-hutan-wisata-puntikayu-palembang). di akses pada 1 Maret 2017.

Antoni, 2016. Radar Palembang. Penambahan Fasilitas Diobjek Wisata Punti Kayu Palembang, terbit Senin 27 Desember 2016 14:22 WIB (Online). http://www.radar-palembang.com/liburpanjang-objek-wisata-diserbu. di akses pada 1 Maret 2017.

Arikunto, Suharsimi. 2010. Prosedur Penelitian Suatu Pendekatan Praktik. Jakarta: PT Rineka Cipta.

Desmita, 2010. Psikologi Perkembangan. Bandung: PT Remaja Rosdakarya.

Stevianus, 2014 "Pengaruh Atraksi Wisata, Fasilitas Dan Kualitas Pelayanan Terhadap Kepuasan Pengunjung Di Taman Margasatwa Ragunan Jakarta' Jurnal Ekonomi Bisnis Volume 19 No. 3, Desember 2014. Universitas Gunadarma.

Suchaina, 2014. "Pengaruh Kualitas Fasilitas Sarana Dan Prasarana Terhadap Peningkatan Jumlah Pengunjung Wisata Danau Ranu Grati', Jurnal Psikologi September 2014, Vol. II, No. 2. STKIP PGRI Pasuruan.

Wardiyanto. 2011. Perencanaan pengembangan pariwisata. Bandung: CV Lubuk Agung. 